\title{
Breach of Duty: A Disappearing Element of the Action in Negligence?
}

All causes of action in tort, like all causes of action generally, are constituted by elements or ingredients. It is often the case that these elements are not crisply separated from each other. That is certainly so in relation to the cause of action in negligence, it having regularly been pointed out that none of its elements is selfcontained. Denning L.J. took that view further than most. In Roe v Minister of Health [1954] 2 Q.B. 66 at 86, he asserted: "you will find that the three questions, duty, causation, and remoteness, run continually into one another. It seems that they are simply three different ways of looking at one and the same problem". However, more commonly it is accepted that although the various elements of the tort of negligence overlap, they nonetheless retain separate identities. Thus, determining whether the tort of negligence has been committed is not generally understood as requiring a single homogeneous enquiry but an analysis whereby one examines each element of the action seriatim in order to determine whether it is present. This conventional understanding was embraced by Lord Simons, delivering the advice of the Privy Council in Overseas Tankship (UK) Ltd v Morts Dock \& Engineering Co Ltd [1961] AC 388 at 425, when he said: "It is, no doubt, proper when considering tortious liability for negligence to analyse its elements and to say that the plaintiff must prove a breach of duty owed by him to the defendant, a breach of that duty by the defendant, and consequent damage".

The conventional understanding that the tort of negligence comprises discrete elements is being attacked by stealth, with the courts quietly but surely placing increased pressure on the distinctions that have been traditionally drawn between the tort's ingredients. The recent decision of the Court of Appeal in Darnley $v$ Croydon Health Services NHS Trust [2017] EWCA Civ 151 is an important development in this regard in that it contributes significantly to the erosion of the customary divide between the duty of care and breach elements of the action in negligence. The consequence of that erosion is that cases that would previously have been understood as being breach cases are increasingly being treated as - and only as - duty cases. In short, contrary to the conventional structure of the tort of negligence, the breach element of the action is slowly but surely disappearing.

The claimant in Darnley had been attacked by unknown assailants and had received a serious blow to his head. He was conveyed by a friend to hospital whereupon the claimant presented himself to a receptionist. The receptionist told the claimant to wait in the waiting area and added that he would not be seen for up to four or five hours. That information was incorrect. The hospital's triage system required the claimant to be seen by a nurse within 30 minutes. The triage nurse would, in turn, decide how quickly the claimant would see a doctor. After waiting for 19 minutes, and before he had been seen by the nurse, the claimant elected to go home. The claimant's condition deteriorated and an ambulance was summoned and the claimant was taken back to hospital. A scan revealed that the claimant urgently needed surgery, which the claimant underwent. However, the claimant had already suffered serious and permanent injury on account of the delay in his being treated. 
The claimant commenced proceedings for damages and the defendant NHS trust admitted that had the claimant been treated promptly, he would have made a full recovery. Expert witnesses agreed that the claimant should have been seen by the triage nurse within 30 minutes of arrival at the hospital. However, the trial judge concluded, among other things, that it was not fair, just and reasonable to impose a duty of care on the defendant's reception staff to give accurate information about waiting times, and the claimant's action consequently failed ([2015] EWHC 2301 (QB), [2015] Med. L.R. 506). An appeal to the Court of Appeal was dismissed by a majority (Jackson and Sales L.JJ.; McCombe L.J.). The majority reasons in Darnley similarly concentrated on whether the defendant owed the claimant a duty. That focus was surprising given that it is, of course, trite law that hospitals owe a duty to their patients. (The claimant was certainly a patient (or analogous to a patient) on account of his having presented himself at the hospital's accident and emergency department, and no member of the court seemed to suggest otherwise, with all of the Lords Justices referring repeatedly to the claimant as a "patient".) Accordingly, on traditional principles, Darnley is not, in fact, a duty of care case at all. Rather, properly understood, the issue was whether the defendant had breached its duty in giving, by its receptionist, inaccurate information to the claimant.

The error that the court committed in Darnley is, unfortunately, far from an isolated one. Judges, by over-specifying the content of the duty, routinely treat breach cases as though they were duty cases (another recent illustration is Southern $v$ Adventure Forest Limited [2016] EWCA Civ 1178 at [31], in which the court held that an occupier did not owe an invitee a duty of care in respect of a particular danger on the premises). Judges who commit the error concerned typically utter formulae such as: "there was no duty of care owed by the defendant in the present case to do $\phi$ because the reasonable person in the defendant's position would not have done $\phi$. ." However, the structure of that phrase reveals immediately that the duty of care element is not in play at all. The very fact that the court is discussing what the reasonable person in the defendant's position would have done indicates that the dispute is actually about the breach element, that being the only element of the action in negligence that is concerned with the satisfactoriness of the defendant's conduct.

That Darnley was actually a breach case emerges particularly clearly from the fact that all of the judges, despite framing the issue as being one of duty, had much to say about what the reasonable person in the position of the defendant would have done. Sales L.J., for example, referred to the fact that patients in accident and emergency departments cannot expect perfectly accurate information regarding waiting times (at [87]). Similarly, Jackson L.J. referred to the fact that waiting areas in accident and emergency departments are "not always havens of tranquillity" and that staff often have to operate under difficult conditions (at [54]). These facts classically pertain, of course, to the breach element of the action in negligence. The reasonable person takes reasonable rather than perfect care, and the reasonable person will often need to attend to competing responsibilities and labour under challenging circumstances.

Pursuant to established doctrine, Darnley should have been analysed as follows. Any suggestion that the defendant did not owe the claimant a duty of care should have been given short shrift. That is because Darnley was completely lacking in features that 
could possibly be thought to have given rise to any duty issue. The parties were within an established duty category. The damage complained of was personal injury rather than (for example) pure mental or economic harm. Neither was there any suggestion that Damely involved a mere omission. It follows, and follows straightforwardly, that a duty of care was owed to the claimant. The only question in Darnley, relevantly, was whether the defendant breached its duty.

The late Tony Weir rightly decried in his Introduction to Tort Law ( $2^{\text {nd }}$ ed, Oxford 2006), 33 (footnote omitted) the tendency of judges to elide the duty element of the tort of negligence with its other elements, which elision is unacceptance where established doctrine insists that the tort comprises discrete ingredients. With reference to the decision in Sam v Atkins [2005] EWCA Civ 1452, [2006] R.T.R. 14, Weir wrote:

"In a quite simple case where the defendant motorist collided with a pedestrian who suddenly stepped out from behind a parked vehicle which blocked the defendant's vision, the trial judge held that though the defendant was negligent in driving too fast, her negligence did not cause the injury. The Court of Appeal correctly dismissed the claimant's appeal, but held that the trial judge had given the wrong reason: the right reason, forsooth, was that the motorist owed the pedestrian no duty! In fact, the trial judge was quite correct. Although the defendant was driving faster than was safe in the circumstances, the accident could only have been avoided if she had been driving much more slowly than proper care required; accordingly, her excess speed did not contribute to the injury, for it would have occurred had she been driving quite properly. To decide the case on the ground of "no duty' rather than, as the trial judge did, on causation, is decidedly peculiar."

Without passing judgment on whether the duty of care element should cannibalise other parts of the action in negligence, it is clearly unacceptable for this process to occur surreptitiously and other than at the ultimate appellate level.

James Goudkamp Keble College, Oxford 